\begin{tabular}{c} 
International Journal of Engineering \& Technology, $7(3.21)(2018) 238-242$ \\
International Journal of Engineering \& Technology \\
SPC \\
Website: $\frac{\text { www.sciencepubco.com/index.php/IJET }}{\text { Research paper }}$ \\
\hline
\end{tabular}

\title{
Are the Effects of Age Still Relevant in Predicting Malaysian Investors' Risk-Taking Behavior in Stock Market?
}

\author{
Audrey Lim Li Chin ${ }^{1}$, Arfan Shahzad ${ }^{2}$ \\ ${ }^{1}$ Multimedia University Melaka \\ ${ }^{2}$ Universiti Utara Melaka \\ *Corresponding author E-mail: audreylim8@gmail.com
}

\begin{abstract}
The role of age in moderating investor's self-confidence bias, herding, conservatism bias, familiarity bias, and regret in risk-taking behavior is explored using data collected from retail investors in Melaka, Selangor, and Wilayah Persekutuan (W.P.) Kuala Lumpur. As indicated in data analysis by Partial Least Squares Structural Equation Modelling (PLS-SEM), age plays an important moderating role in herding, regret, and self-confidence bias in investor's risk-taking behavior. While younger investors who tend to herd are more risk averse and feel more regret in risk-taking than the older group, older investors seem to exhibit a higher level of self-confidence bias than younger investors. However, the risk- taking distribution between the age groups indicates no significant difference. Thus, the readiness in greater levels of risk acceptance depends on the individuals' preference towards herding, regret, and self-confidence bias. Furthermore, this study also address contradictions in the existing literatures that fuels stereotyping and discrimination based on age. Therefore, age stereotype should be avoided when formulating microstructure strategies to raise the investor's participation in the stock market.
\end{abstract}

Keywords: Age; Risk-Taking; Herding; Conservatism; Familiarity Bias; Regret; Self-Confidence Bias

\section{Introduction}

Since the Asian financial crisis of 1997-1998, the participation of investors, particularly individual investors, has been lacklustre. This is confirmed by the slow growth in the number of central depository system (CDS) accounts (1). Between 2009 and 2013, the number of CDS accounts only grew from 4 million to 4.3 million despite the liberalisation of the brokerage fees in 2002. Moreover, the trading has been made easier, if not cheaper, for anyone who is interested in trading with the advent of online trading (The Edge Malaysia, 2015). Figure 1 shows the categories of CDS account holders: 54 per cent of CDS holders are dormant holders with no trading and no shares and 11 per cent are inactive, with no trading for 3 years but some shares. Only 5 per cent of CDS holders are frequent traders who trade at least once a month, and 30 per cent of CDS holders trade at least once in 3 years, excluding those who trade at least once a month (2). Consequently, the sluggish growth in the CDS accounts has severely impacted the profit margin in the stockbroking industry.

Hence, the risk-taking behavior of investors in the Malaysian share market needs to be examined to raise their level of participation. For instance, if they do take risks or invest, what drives them to take risks? Is it their inherent traits or personality that causes them to assume risks or is it due to certain influences? Likewise, if they take fewer risks or do not invest, is it consistently due to their personality trait of risk aversion or because of certain circumstances? There are many studies in the area of age in risk-taking but little attention is paid to how the role of age in psychological factors affects their participation in the financial market. Furthermore, some older investors may have become risk averse due to their past experience with the Asian financial crisis, but very little attention is devoted to quantifying the psychological impact of this crisis on older investors in the existing literature. Besides this, Gen Y may not be investing due to their lack of financial knowledge. Only 28 per cent of them are confident about their financial literacy (3)

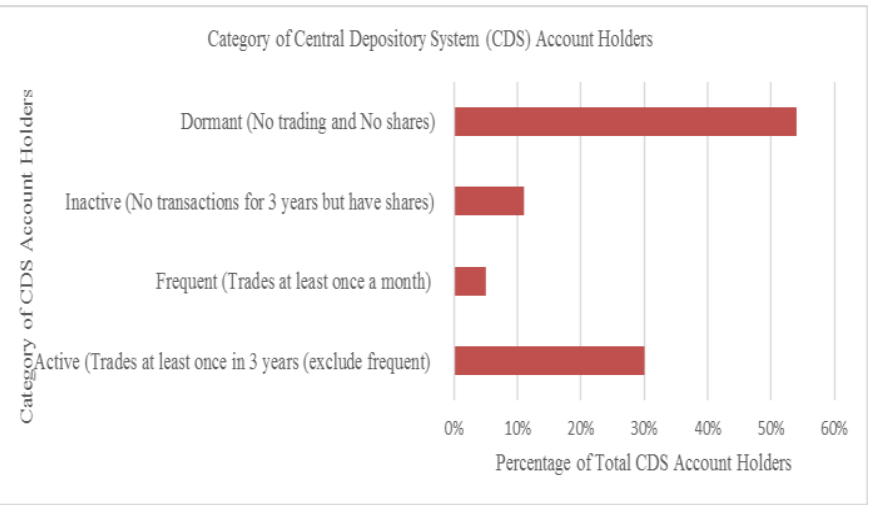

Fig. 1: Category of Central Depository System (CDS) Account Holders

Thus, the moderating role of age in psychological-based bias such as self-confidence bias, herding, conservatism bias, familiarity bias, and regret of investors' risk-taking behavior is explored in this study. Besides this, this study also aims to resolve some of the inconsistencies in the existing literature by confirming the age effects in financial risk taking as not many prior studies used a combination of Multi-Group Analysis (MGA) in Partial Least Squares (PLS) and Measurement Invariance of Composite Models (MICOM) analysis. 


\section{Literature Review}

\subsection{Risk-Taking}

Risk attitude is defined by Adam (4) as a "construct of risk propensity and as a person's desire to either avoid or take risks". Attempts are made in past studies to understand risk-taking behavior through the linkages among the risk profile parameter, the model for financial risk-taking behavior with variables such as risk tolerance, risk need, risk profile, and risk perception (5). As subjective risk preferences of investors could not be accurately assessed by financial advisors, formulation of instruments for risk assessmen is needed for effective evaluation of subjective risk profile and risk preferences for investors (6). However, the phenomenon of global risk hedging and the increasing usage of credit derivative products among investors as well as financial institutions seem to suggest the inadequacies of the expected utility theory of riskaverse agents, put forth by Von Neumann and Morgenstern (7) to address the risks interrelated with complex financial tools such as hedge funds.

In addition to this, the study by Herriott (8) contends that, because people consistently behave in a certain manner across situations, an individual's personality traits in certain circumstances can be measured. On the contrary, Cho and Lee (9) state that risk-taking propensity is more of a tendency that is related to behavior instead. On the other hand, Slovic (10) suggests that the previous experiences of an individual exert an impact on risk-taking propensity. In contrast, Kahneman and Tversky (11) document that different responses given by individuals are possible even when they are given the same problem due to the framing effect, which is also known as the reflection effect. Primarily, trait psychology suggests that there is consistency in the risk propensity across scenarios, while Kahneman and Tversky (1979) postulate that different outcomes could be unintentionally generated due to framing effects in the decision making. This finding is in agreement with study done by Nicholson, Soane (12) on the evaluation of the prospect theory by in which they demonstrate that in different situations different levels of risk taking among individuals are displayed.

There are studies that challenge the standard finance and standard behavioral finance. For instance, some studies document that personality affects investment choices and outcomes. Durand, Newby, Peggs, and Siekierka (2013) find that the "availability heuristic" and the "disposition effect" are related to student investors' personality in Australia. By applying "Norman's Big Five Preference for Innovation" and the propensity for risk-taking from "Jackson's Personality Inventory" as well as "Bem's Sex-Role Inventory", their study lends support to the earlier study conducted by Durand, Newby, \& Sanghani, (2008).

Few studies attempt to investigate the investment behavior in $\mathrm{Ma}$ laysia. For instance, Mansor and Lim (15) analyse Malaysian individual investors to gain some insights into their investment practices and behavior. In their study, Chinese investors are found to be the main and most active participants in the stock market. As their results show, investors tend to speculate, practise random stock picking, and trade based on rumours during bullish periods. However, they become more rational, as more than 50 per cent of the respondents return to using "fundamental analysis" during bearish years. About 26 per cent of the respondents practise "technical analysis" during bearish periods compared with only 16 per cent during bullish years. Wong and Lai (2010) explore the investment style of investors in Malaysian Stock Market and find that psychological biases: representativeness, price anchoring, loss aversion, and overconfidence affects investment decisions. The disposition effect, which is related to loss aversion, is found among Malaysian IPO investors, as suggested by Chong (17). Besides this, while evidence of herding activities is found in nonprivate placements in technology-driven sector, herding amongst the informed investors is found in private placement for technology-driven sector as well as consumer product sector as suggested by Dehghani and Sapian (18). In addition to this, Lai, Tan (19) investigate the institutional and retail investors' trading activities and their behavior in the Malaysian share market during bullish and bearish years. Their studies highlight that individual investors appear to be overconfident during both bullish and bearish years, although there is evidence of self-constraint among investors with a concern for liquidity when making investments.

According to the Manulife Investor Sentiment Index published in Digital News Asia (20), Malaysian investors have less investment experience due to lower investment ownership rates than their Asian counterparts. This index is a proprietary survey that is conducted quarterly in the Asian region across eight markets - Hong Kong, China, Taiwan, Japan, Singapore, Indonesia, and the Philippines - to track investors' attitudes towards key investment products. Besides this, Malaysian investors hardly engage expert or online inputs for investment advice and instead, turn to their family and friends for investment decisions. This survey also indicates that Malaysian investors display overconfidence in their financial planning abilities despite their level of financial literacy being relatively low. However, only 27 per cent of them feel that they could manage their investment compared with investors from China (36 per cent), Indonesia (41 per cent), and the Philippines (53 per cent). Confidence in investment skills of Malaysian investors is visibly lacking and is undermined by pessimistic view that their stock's value will drop as documented by (21).

Chiang and Zheng (22) demonstrate the existence of herding behavior globally, particularly in the advanced and emerging stock markets in Asia, including countries such as Malaysia. In addition to this, the evidence suggests that dispersions in the US stock market returns are contributing factors that account for herding behavior in non-US markets. Qiao, Chiang (23) reinforce the idea that herding behavior has time-varying component which is comoving across markets for all nine Asian markets, including Malaysia. Brahmana, Hooy (24) also propose that herding behavior is an irrational determinant of the "day-of-the-week" anomaly in relation to investors' "Monday irrationality", especially in industries in the category of small capitalisation. Monday irrationality or the day-of-the-week phenomenon is deemed to be a stock market anomaly whereby the daily returns on certain days display significant difference from other days. In addition to this, research carried out by Deutsche Asset \& Wealth Management, which is published in the Financial Times Ltd. (25), contends that Malaysian investors are the least tolerant of losses in mutual funds compared with investors in Belgium, Sweden, Germany, and Switzerland. Hence, there are studies in the area of psychological factors in risk-taking but little attention is paid to how the role of age in psychological factors affects investor risk-taking participation in the market.

\subsection{The Role of Age in Risk-Taking}

The decline in the propensity to take risk across the life span in many countries is documented by Mata, Josef (26) with flatter age-risk curves and acceptance of higher risk-taking level by countries with higher level of hardships. However, higher level of general risk taking in the decision making with regards to specific domains of financial, ethical, and recreational, can be accounted for by "Horne and Östberg's eveningness" put forth by Horne and Ostberg (27). Furthermore, higher level of risk-taking is regardless of the factors such as sex, age, ethnicity, or personality traits of individuals as maintained by Ponzi, Wilson (28). Although risk perception and dimensions for personality of the "Big Five Inventory" are found to be highly associated with risk-taking, these factors remain irrelevance in the risk taking's prediction by eveningness. According to Reily and Brown (29), the net worth, investment strategies, and risk tolerance level of investors tend to change over their lifetime. In addition to this, older investors might be more financially stable than younger ones, might have settled many of their outstanding debts, may have earnings that exceed their expenses, and may still have a long investment horizon, as suggested by $(30)^{30}$ Ibbotson, Milevsky, Chen, and Zhu (2007). The study performed by Varga and Ulbert (2005) (as cited 
in Berlinger and Váradi, 2015), contends that young people undertakes higher level of risk than the elderly. On the other hand, some older investors may have been affected by risk aversion and loss aversion due to their bad past experience with the Asian financial crisis, but the literature to date pays very little attention to quantifying the psychological impact of this crisis on older investors. Members of Gen Y may not be investing either due to their lack of financial knowledge. In a report titled Gen Y: Living on the financial edge, released by the Asian Institute of Finance (AIF) in 2015, only 28 per cent of the members of Gen $\mathrm{Y}$ are found to be confident about their financial literacy and most of them are stressed financially.

Essentially, the differences in risk taking distribution level between the younger and older group of investors if any, are an inherent trait personality or could be accounted for by individual's propensities concerning psychological biases such as selfconfidence bias, herding, conservatism bias, familiarity bias, and regret, are confirmed in this study. Hence, these hypotheses are developed:

H1: Age moderates herding in Malaysian investors' risk-taking.

$\mathrm{H} 2$ : Age moderates conservatism bias in Malaysian investor's risk-taking.

H3: Age moderates familiarity bias in Malaysian investor's risktaking.

H4: Age moderates regret in Malaysian investor's risk-taking.

H5: Age moderates self-confidence bias in Malaysian investor's risk-taking.

H6: Older investors assume more risk than younger investors.

\section{Methodology/Materials}

As it is not possible to identify the actual total population of investors, this study elicits responses from 600 retail investors in Melaka, Selangor, and Wilayah Persekutuan (W.P.) Kuala Lumpur non-randomly using questionnaire. However, due to omission for missing data, eventually, only 362 sets are usable with the return of 391 sets. Applying the the research framework developed by Lim (2017), and considering the suggestions by Podsakoff, MacKenzie (32), issues concerning "Common method variance" in the data needs to be addressed. The measurement and structural model with regards to their validity and reliability are tested using Smart-PLS 3.0 software. In evaluating "convergent validity", and "discriminant validity" in reflective measurement models, apart from using Fornell and Larcker (33), heterotrait-monotrait ratio (HTMT) criterion is also being used. On the other hand, the evaluation for formative measurement models involves convergen validity, collinearity assessments among the items in the construct, and the formative items' relevance to the formative construct (34, $35)$. The $R^{2}$ which is the coefficient of determination, $Q^{2}$, predictive relevance, $\mathrm{f}^{2}$ and $\mathrm{q}^{2}$ effect sizes are then used to evaluate formative measurement models (Hair et. al, 2013). The age of the investor is divided into two categories: a younger group (18-30) and an older group (31 and above) before multi-group analysis (MGA) is conducted to examine the moderating effects of age in self-confidence bias, herding, conservatism bias, familiarity bias, and regret in risk taking. This split is decided based on the definition of young savers by HSBC research in the news article titled "18-30 year olds save more than any other age group" reported by (36).

The results of PLS-MGA for age effect is confirmed further with permutation procedure in "SmartPLS 3.0" with measurement invariance assessment of Composite Models (MICOM) to analyze the invariances for Configural and Compositional as well as composite mean values and variances for equality (37). Further to this, non-parametric test such as Mann-Whitney U in SPSS is conducted to test the risk-taking distribution level between younger and older investors in general, as the data is not normally distributed.

\subsection{Research Framework}

This study adopts the research framework developed by Lim (38) that investigate the interactions between biases such as selfconfidence bias, herding, conservatism bias, familiarity bias, regret, with risk-taking trait personality. A total of 43 items in the questionnaire are adapted from the past studies as cited in Lim (2017).

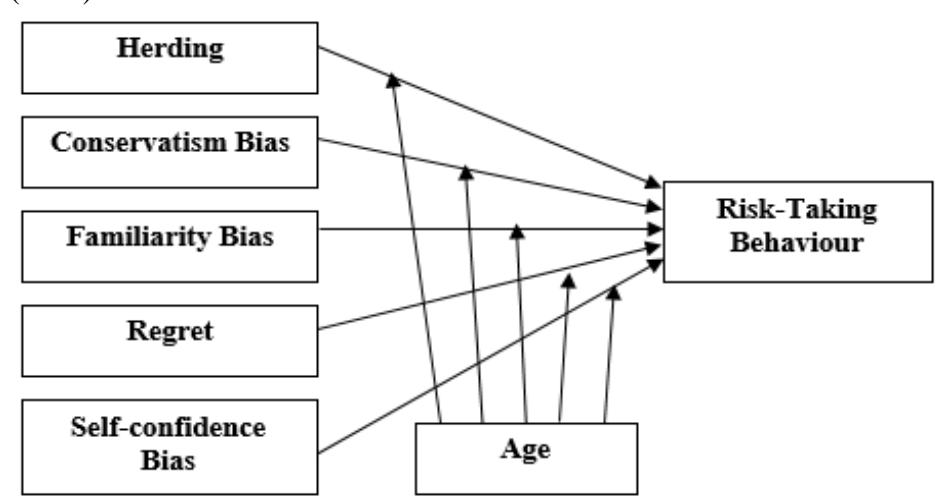

Fig. 1: Research Framework

\section{Results and Findings}

All the respondents surveyed are Malaysian. As indicated in Table $1,59.9$ percent (217) of the respondents are male and 40.1 percent (145) are female. While 41.4 percent (150) of the respondent are single, 57.7 percent (209) are married. The remaining 0.8 percent (3) ticks the "other" category. The largest group of investors is between the age of 31 and 45 years old, equating to 43.1 percent (156) of the total respondents, 33.4 percent (121) investors are in the age group between 18 and 30; 19.9 percent (72) of the investors in the age group between 46 and 60 , and lastly, 3.6 percent (13) of the investors in the age group of above 60. A total of 52.2 percent (189) of them are working adults. Self-employed investors comprise 34.5 percent (125), student 5.8 percent (21), and retirees 5.5 percent (20). The remaining 1.9 percent (7) of the respondents are either unemployed or a housewife.

Table 1: Respondents' Demographic Profile

\begin{tabular}{|l|c|c|}
\hline \multicolumn{3}{|c|}{ Table 1: Respondents' Demographic Profile } \\
\hline Demographic & Frequency (n=362) & Percent (\%) \\
\hline Gender & 217 & 59.9 \\
\hline Male & 145 & 40.1 \\
\hline Female & & \\
\hline Marital Status & 150 & 41.4 \\
\hline Single & 209 & 57.7 \\
\hline Married & 3 & .8 \\
\hline Other & & 33.4 \\
\hline Age & 121 & 43.1 \\
\hline $18-30$ & 156 & 19.9 \\
\hline $31-45$ & 72 & 3.6 \\
\hline $46-60$ & 13 & 5.8 \\
\hline Above 60 & & 52.2 \\
\hline Occupation & 21 & 34.5 \\
\hline Student & 189 & 5.5 \\
\hline Working Adult & 125 & 1.9 \\
\hline Self-employed & 20 & \\
\hline Retired & 7 & \\
\hline $\begin{array}{l}\text { Other(Unemployed, } \\
\text { Housewife) }\end{array}$ & & \\
\hline
\end{tabular}

\subsection{Results of Hypothesis Testing for PLS-MGA in Risk-Taking between Younger and Older Group of In- vestors}

As shown in Table 2, a difference between younger and older group is significantly found for herding, regret and self-confidence bias $(\mathrm{p}<0.05)$. Based on the results in Table 3, for MICOM step 2, the compositional invariance for herding, regret and self- 
confidence bias is established ( $p>0.05$ ). Further to this, full measurement invariance is established for both the herding and regret as there are no significant indication of differences in the mean and variance between younger and older group $(p>0.05)$ in Table 4 and Table 5 for MICOM step3. In contrast, while the equality of variance is assumed, the results for equality of composite's mean for self-confidence bias reveal partial invariance measurement $(\mathrm{p}<0.05)$ as indicated in Table 4 . Nevertheless, age could still be considered playing a significant moderating role in selfconfidence bias of risk-taking. Further to this, the results imply that younger investors who tend to herd are more risk averse than the older group of investors. This could be due to the level of sophistication and financial experience of investors, which is often associated with their income, occupational status, and trading frequency (Feng \& Seasholes, 2005; Dhar \& Zhu, 2006; Choe \& Eom, 2009). Younger investors could be relatively less sophisticated, lack experience, and thus be more susceptible to momentum bias reinforced by herding than older investors.

In addition to this, the findings of this study suggest that the younger group seems to feel more regret in risk taking than the older group. In other words, the greater prevalence of the disposition effect in risk taking among younger investors consequently induces more regret in the younger group than the older group, as suggested by the results. This is probably because the sophistica- tion level of older investors could have reduced the disposition effect (39-41). In addition, younger investors, especially those with a low income, may make poor decisions due to their low selfregard, which could subsequently lead to a greater disposition effect (42).

The results also suggest that older investors seems to exhibit higher level of self-confidence bias compared to younger investors. This is intuitive, as older investors compared with younger ones might be more financially stable, might have settled many of their outstanding debts, may have earnings that exceed their expenses, and may still have a long investment horizon (Ibbotson et al., 2007). Thus, the willingness among older investors to expend more effort on learning new tools or software for share analysis may eventually engender a higher level of self-confidence bias among older investors.

In contrast, the relationship between conservatism bias and risk taking is not affected by age. This is expected, as there is no substantial evidence in the prior studies that documents the age effect on conservatism bias in risk taking. Furthermore, age does not play any moderating role in the relationship between familiarity bias and risk taking. This is also expected, as there is paucity in the evidence that supports the notion of an age effect on familiarity bias in risk taking in the past literatures. In view of this, only $\mathrm{H} 1, \mathrm{H} 4$ and $\mathrm{H} 5$ are supported while $\mathrm{H} 2$ and $\mathrm{H} 3$ are not supported.

Table 2: Results of Hypothesis Testing for PLS-MGA in Risk-Taking between Younger and Older Group of Investors

\begin{tabular}{|l|l|c|c|c|c|}
\hline Hypothesis No. & Hypothesised Path & Path Coefficient & \multirow{2}{*}{$\begin{array}{c}\text { Path Coefficients } \\
\text { Difference }\end{array}$} & \multirow{2}{*}{ P-Value } \\
\cline { 3 - 4 } & & Younger Group & Older Group & -0.225 & $0.008^{* *}$ \\
\hline H1 & Herding $\rightarrow$ Risk-Taking & -0.262 & -0.037 & 0.101 & 0.189 \\
\hline H2 & Conservatism Bias $\rightarrow$ Risk-Taking & 0.089 & -0.012 & -0.118 & 0.127 \\
\hline H3 & Familiarity Bias $\rightarrow$ Risk-Taking & 0.052 & 0.171 & 0.197 & $0.031^{*}$ \\
\hline H5 & Regret $\rightarrow$ Risk-Taking & 0.261 & 0.065 & -0.252 & $0.017^{*}$ \\
\hline
\end{tabular}
*** $\mathrm{p}<0.01, * \mathrm{p}<0.05$

Table 3: Measurement Invariance Assessment of Composite Models (MICOM-Step 2) for Compositional invariance

\begin{tabular}{|l|c|c|c|}
\hline \multirow{2}{*}{ Construct } & \multicolumn{3}{|c|}{ Correlation (Younger and Older Group ) } \\
\cline { 2 - 4 } & Original Correlation & Permutation Mean & 0.404 \\
\hline Herding & 0.794 & 0.81 & 0.834 \\
\hline Regret & 0.763 & 0.221 & 0.904 \\
\hline
\end{tabular}

Table 4: Measurement Invariance Assessment of Composite Models (MICOM-Step 3) for Equality of Composite’s Mean

\begin{tabular}{|l|c|c|c|}
\hline \multirow{2}{*}{ Construct } & \multicolumn{3}{|c|}{ Mean difference (Younger and Older Group) } \\
\cline { 2 - 4 } & Original Mean & Permutation Mean & P-Value \\
\hline Herding & -0.148 & 0.001 & 0.096 \\
\hline Regret & 0.054 & 0.001 & 0.341 \\
\hline Self-Confidence Bias & -0.192 & -0.001 & 0.036 \\
\hline
\end{tabular}

Table 5: Measurement Invariance Assessment of Composite Models (MICOM-Step 3) for Equality of Variance

\begin{tabular}{|l|c|c|c|}
\hline \multirow{2}{*}{ Construct } & \multicolumn{2}{|c|}{ Variance difference (Younger and Older Group) } \\
\cline { 2 - 4 } & Original Variance & \multicolumn{2}{|c|}{ Permutation Mean } \\
\hline Herding & 0.064 & -0.002 & -0.005 \\
\hline Regret & 0.127 & 0.153 & -0.006 \\
\hline
\end{tabular}

\subsection{Independent-Samples Mann-Whitney U Test}

As results in PLS-MGA suggest risk-taking level between the groups exhibits difference when these groups are biased by the psychological factors such as herding, regret, and self-confidence bias, further bivariate analysis is conducted using Mann-Whitney $\mathrm{U}$ Test, a non-parametric independent $\mathrm{t}$-test to determine if risk taking distribution level is different between younger and older group of investors in view of the violation of assumptions for Independent T-Test (35). There is no apparent difference in the risk-taking distribution level between older and younger group $(\mathrm{p}$ $>0.05$ ) as indicated in the test results in Table 6. Hence, in general, older group of investor does not seem to assume more risks than the younger group. This result is unexpected, as younger people have a tendency to assume more risks than the elderly (43). In- stead, the study suggests that the differences in inclination towards psychological biases, such as self-confidence bias, herding, and regret, between the groups account for the differences between the groups in risk-taking behavior. Thus, H6 in this research is not supported.

Table 6: Results of Hypothesis Testing on Risk-Taking Distribution Level between Younger and Older Group of Investors

\begin{tabular}{|l|l|c|}
\hline Hypothesis No & \multicolumn{1}{|c|}{ Statement } & P-Value \\
\hline H6 & $\begin{array}{l}\text { The risk-taking distribution level } \\
\text { is different between the age } \\
\text { groups. }\end{array}$ & 0.967 (NS) \\
\hline
\end{tabular}

NS=Not Significant 


\section{Conclusion}

The younger group seems to feel more regret in risk taking than the older group. In other words, the results suggest that the higher level of disposition effect experienced by younger investors leads to more regret in comparison with the older group. Furthermore, older investors seems to have higher self-confidence bias than younger investors, as older investors might be more financially stable, might have settled many of their outstanding debts, may have earnings that exceed their expenses, and may still have a long investment horizon. Besides this, the difference is not found in the risk-taking distribution level between the younger and the older group. This further suggests that generally the older group of investors does not seem to assume more risk than the younger group. Instead, the study implies that the difference in tendency towards psychological factors, such as self-confidence bias, herding, and regret, between the groups accounts for differences in the risktaking behavior of investors. Hence, this study signifies that risk taking is a behavior that is biased by psychological factors and thus, not an innate personality for both group of investors. In addition to this, the findings in this study shed light on conflicting views in the past literature pertaining to irrational risk-taking by investors due to age- based stereotyping and discrimination. The sample could be more representative if the sample size could be expanded by including other regions in Malaysia. Furthermore, sampling technique could be improved for further studies if factors such as race, income, and field of occupation are considered.

\section{References}

[1] Bursa retail participation weak [Internet]. 2015 [cited 15 July 2016]. Available from: http://www.themalaysianinsider.com/business/article/bursa-retailparticipation-weak-the-edge-weekly

[2] Declining foreign participation in local equities normal [Internet]. 2014 [cited 10 November, 2015]. Available from http://www.mysinchew.com/node/102395.

[3] Gen Y: Living on the financial edge [Internet]. 2015 [cited 15 October 2016]. Available from: http://www.aif.org.my/clients/aif_d01/assets/multimediaMS/news/finan ce_matters_understanding_gen_y.pdf.

[4] Adam J. Risk. London: UCL Press; 1995.

[5] Nobre LHN, Grable JE. The role of risk profiles and risk tolerance in shaping client investment decisions. Journal of Financial Service Professionals. 2015;69(3):18-21.

[6] Finke MS, Guillemette MA. Measuring Risk Tolerance: A Review of Literature. Journal of Personal Finance. 2016;15(1):63.

[7] Von Neumann J, Morgenstern O. Theory of games and economic behavior: Princeton University Press Princeton, NJ; 1945.

[8] Herriott P. Assessment and selection in organisations: Methods and practice for recruitment and appraisal. Chichester: John Wiley \& Sons; 1990.

[9] Cho J, Lee J. An integrated model of risk and risk-reducing strategies. Journal of Business Research. 2006;59(1):112-20.

[10] Slovic P. Psychological study of human judgment: Implications for investment decision making. The Journal of Finance. 1972;27(4):77999.

[11] Kahneman D, Tversky A. Prospect theory: An analysis of decision under risk. Econometrica: Journal of the Econometric Society. 1979:263-91.

[12] Nicholson N, Soane E, Fenton-O'Creevy M, Willman P. Personality and domain-specific risk taking. Journal of Risk Research. 2005;8(2):15776.

[13] Durand RB, Newby, R., Peggs, L., \& Siekierka, M. Personality. Journal of Behavioural Finance. 2013;14:116-33.

[14] Durand RB, Newby R, Sanghani J. An intimate portrait of the individual investor. The Journal of Behavioral Finance. 2008;9(4):193-208.

[15] Mansor M, Lim C. Profile of individual investors in the Klang area Capital Markets Review. 1995;3:1-15.

[16] Wong WC, \& Lai, M. M. Investor behaviour and decision-making style: A Malaysian perspective. Institut Bank - Bank Malaysia. 2010:3-11.

[17] Chong F. Disposition effect and flippers in the Bursa Malaysia. The Journal of Behavioral Finance. 2009;10(3):152-7.

[18] Dehghani P, Sapian RZZ. Sectoral herding behavior in the aftermarket of Malaysian IPOs. Venture Capital. 2014;16(3):227-46.
[19] Lai M-M, Tan S-H, Chong L-L. The behavior of institutional and retail investors in Bursa Malaysia during the bulls and bears. Journal of Behavioral Finance. 2013;14(2):104-15.

[20] Digital News Asia. Malaysia investors among most vulnerable in Asia: Manulife survey. 2014

[21] Lim ALL. Psychological biases and investor behaviour: Survey evidence from Malaysian stock market. International Journal of Social Science, Economics and Arts. 2012;2(2):67-73.

[22] Chiang TC, Zheng D. An empirical analysis of herd behavior in global stock markets. Journal of Banking \& Finance. 2010;34(8):1911-21.

[23] Qiao Z, Chiang TC, Tan L. Empirical Investigation of the Causal Relationships Among Herding, Stock Market Returns, and Illiquidity: Evidence from Major Asian Markets. Review of Pacific Basin Financial Markets and Policies. 2014;17(03):1-27.

[24] Brahmana R, Hooy CW, Ahmad Z. The Role of Herd Behaviour in Determining the Investor's Monday Irrationality. Asian Academy of Management Journal of Accounting \& Finance. 2012;8(2):1-20.

[25] Investors across the world show very different traits [Internet]. 2015 [cited 12 January, 2016]. Available from: http://www.ft.com/cms/s/0/59d83d6e-04de-11e3-9e7100144feab7de.html\#axzz3cVjY14IK.

[26] Mata R, Josef AK, Hertwig R. Propensity for risk taking across the life span and around the globe. Psychological Science. 2016;27(2):231-43.

[27] Horne JA, Ostberg O. A self-assessment questionnaire to determine morningness-eveningness in human circadian rhythms. International Journal of Chronobiology. 1976;4(2):97-110.

[28] Ponzi D, Wilson MC, Maestripieri D. Eveningness is associated with higher risk-taking, independent of sex and personality. Psychological Reports. 2014;115(3):932-47.

[29] Reily F, Brown K. Investment analysis and portfolio management 9th ed. Canada: South-Western College Publisher; 2015.

[30] Ibbotson RG, Milevsky, M. A., Chen, P., \& Zhu, K. X. Research foundation of CFA Institute. Journal of Pension Economics and Finance. 2007;7(3):365-8.

[31] Varga J, \& Ulbert, J. A befektetők hasznossági, illetve értékfüggvényeinek becslési eljárá-sairól (On the estimation processes of the utility and value functions of investors). GKK working paper. 2005.

[32] Podsakoff PM, MacKenzie SB, Lee J-Y, Podsakoff NP. Common method biases in behavioral research: a critical review of the literature and recommended remedies. Journal of Applied Psychology. 2003;88(5):879.

[33] Fornell C, Larcker DF. Evaluating structural equation models with unobservable variables and measurement error. Journal of Marketing Research. 1981:39-50.

[34] Hair JF, Ringle CM, Sarstedt M. PLS-SEM: Indeed a silver bullet. Journal of Marketing theory and Practice. 2011;19(2):139-52.

[35] Field A. Discovering statistics using SPSS. Thousand Oaks, CA: Sage publications; 2009.

[36] 18-30 year olds save more than any other age group [Internet]. 2015 [cited 16 June 2016]. Available from: http://www.yourmoney.com/saving-banking/18-30-year-olds-savemore-than-any-other-age-group/.

[37] Ringle CM, Wende S, Becker J-M. SmartPLS 3. Bönningstedt SmartPLS. GmbH, http://www smartpls Com. 2015.

[38] Lim ALL. Determinants of Risk-Taking Behaviour of Investors in the Malaysian Stock Market. Kedah, Malaysia: Universiti Utara Malaysia; 2017.

[39] Feng L, Seasholes MS. Do investor sophistication and trading experience eliminate behavioral biases in financial markets? Review of Finance. 2005;9(3):305-51.

[40] Dhar R, Zhu N. Up close and personal: Investor sophistication and the disposition effect. Management Science. 2006;52(5):726-40.

[41] Choe H, Eom Y. The disposition effect and investment performance in the futures market. Journal of Futures Markets. 2009;29(6):496-522.

[42] Kadous K, Tayler WB, Thayer JM, Young D. Individual characteristics and the disposition effect: the opposing effects of confidence and selfregard. Journal of Behavioral Finance. 2014;15(3):235-50.

[43] Berlinger E, Váradi K. Risk Appetite. Pénzügyi Szemle/Public Finance Quarterly-Journal of Public Finance. 2015;60(1):49-62 